\title{
SELEKSI KLON BIBIT RUMPUT LAUT, Gracilaria verrucosa
}

\author{
Petrus Rani Pong-Masak"), Bambang Priono"', dan Irsyaphiani Insan") \\ Balai Riset Perikanan Budidaya Air Payau \\ Jl. Makmur Dg. Sitakka No. 129, Maros 90512, Sulawesi Selatan \\ E-mail: litkanta@yahoo.com \\ ") Pusat Penelitian dan Pengembangan Perikanan Budidaya \\ Jl. Ragunan 20, Pasar Minggu, Jakarta Selatan 12540
}

\begin{abstract}
ABSTRAK
Upaya peningkatan produksi rumput laut juga tidak terlepas dari permasalahan, yaitu: ketersediaan bibit unggul dalam jumlah yang cukup, adanya serangan hama dan penyakit, dan faktor pembatas musim tanam. Bibit rumput laut unggul dapat diperoleh dengan menggunakan metode seleksi klon dan bioteknologi (kultur jaringan dan rekayasa gen). Seleksi klon/massa dapat dilakukan dengan mudah dan dapat menghasilkan varietas bibit unggul dalam pertumbuhan relatif cepat, daya tahan terhadap penyakit, dan lingkungan, serta keunggulan spesifik lokasi/kawasan. Keberhasilan budidaya rumput laut sangat dipengaruhi oleh kondisi lingkungan. Karena itu, kegiatan pemilihan bibit yang berupa pelaksanaan seleksi klon harus memperhatikan faktor lingkungan perairan. Variasi kondisi lingkungan perairan di Indonesia yang relatif besar, maka pelaksanaan seleksi klon/massa sangat dianjurkan untuk dilakukan di setiap sentra produksi rumput laut. Tujuan seleksi klon ini adalah untuk mendapatkan bibit unggul varietas rumput laut Gracilaria verrucosa yang cepat pertumbuhannya. Sasaran penerapan metode seleksi klon ini adalah penyediaan bibit unggul untuk mendukung target peningkatan produksi. Selain itu, sasaran dari seleksi klon/ massa adalah penyediaan bibit untuk mendukung pengembangan kebun bibit di setiap sentra produksi.
\end{abstract}

KATA KUNCI: seleksi klon, Gracilaria verrucosa, bibit rumput laut unggul

\section{PENDAHULUAN}

Rumput laut selama ini dikenal sebagai salah satu bahan baku pembuat agar-agar, dikenal sebagai rumput laut jenis Gracilaria sp., termasuk pada kelas alga merah (Rhodophyta) dengan nama daerah yang bermacam- macam, seperti: sango-sango, rambu kasang, janggut dayung, dongi-dongi, bulung embulung, agar-agar karang, agar-agar jahe, bulung sangu, dan lain-lain. Rumput laut marga Gracilaria banyak jenisnya, masing-masing memiliki sifat-sifat morfologi dan anatomi yang berbeda serta dengan nama ilmiah yang berbeda pula, seperti: Gracilaria confervoides, Gracilaria gigas, Gracilaria verrucosa, Gracilaria lichenoides, Gracilaria crasa, Gracilaria blodgettii, Gracilaria arcuata, Gracilaria taenioides, Gracilaria eucheumoides, dan banyak lagi. Beberapa ahli menduga bahwa rumput laut marga Gracilaria memiliki jenis yang paling banyak dibandingkan dengan marga lainnya.

Rumput laut Gracilaria umumnya mengandung ager atau disebut juga agar-agar sebagai hasil metabolisme primernya. Agar-agar diperoleh dengan melakukan ekstraksi rumput laut pada suasana asam setelah diberi perlakuan basa, serta diproduksi dan dipasarkan dalam berbagai bentuk, yaitu: agar-agar tepung, agar-agar kertas, dan agar-agar batangan dan diolah menjadi berbagai bentuk penganan (kue), seperti pudding dan jeli atau dijadikan bahan tambahan dalam industri farmasi. Kandungan serat agar-agar relatif tinggi, karena itu, dikonsumsi pula sebagai makanan diet. Melalui proses tertentu agar-agar diproduksi pula untuk kegunaan di laboratorium sebagai media kultur bakteri atau kultur jaringan.

Budidaya rumput laut jenis Gracilaria dan Eucheuma telah banyak dikembangkan di Indonesia. Berdasarkan data yang ada baik produksi maupun ekspor rumput laut, Indonesia menempati urutan kedua setelah Filipina. Potensi pengembangan rumput laut di Indonesia mencapai 1,11 juta ha dengan produksi diperkirakan mencapai sebesar 167.937 MT per tahun (Anonim, 2005). Usaha budidaya rumput laut masih dapat ditingkatkan baik secara kuantitas maupun kualitasnya dengan dukungan dari berbagai faktor antara lain; teknologi yang sesuai, modal yang memadai, pemanenan yang sesuai umur, penjemuran yang memenuhi standar, dan penetapan jaminan harga. Agar budidaya rumput laut tersebut dapat diusahakan secara berkelanjutan maka dukungan dari berbagai faktor tersebut mutlak harus dilakukan. 
Pada dekade sekarang ini, usaha rumput laut telah berkembang dengan pesat, hal ini disebabkan semakin meningkatnya permintaan pasar baik domestik maupun luar negeri. Namun demikian, permasalahan akan tetap muncul baik secara teknis maupun non teknis, bagi pembudidaya rumput laut, apabila upaya pengembangannya tidak didukung dengan teknologi budidaya, serta pasca panen yang sesuai dan kebijakan pemerintah yang tepat. Secara umum kegiatan budidaya rumput laut telah nyata memberikan konstribusi peningkatan sumber pendapatan masyarakat dan peluang pekerjaan terutama masyarakat di wilayah pesisir (Anggadiredja, 2007). Namun saat ini, ada kekhawatiran bahwa keuntungan yang diterima oleh petani semakin menurun, akibat mutu rumput laut yang dihasilkan tidak sesuai dengan permintaan pasar. Selain itu, juga dikarenakan mutu bibit rumput laut yang dibudidayakan cenderung kurang baik, sering ditemukan adanya penyakit ice-ice (Sulaeman et al., 2005). Penyakit ini disinyalir dapat menyebabkan pertumbuhan rumput laut jadi kurang sempurna, sehingga secara tidak langsung mempengaruhi kandungan agar-agar dalam rumput laut yang dipanen.

Kementerian Kelautan dan Perikanan mempunyai visi untuk menjadikan Indonesia sebagai produsen perikanan terbesar pada tahun 2014. Komoditas yang diharapkan menjadi penyumbang terbesar untuk mencapai visi tersebut adalah rumput laut, dengan target produksi sebesar 10 juta ton dengan target penyediaan benih sekitar 1 juta ton (Anonim, 2010). Rumput laut menjadi komoditas utama karena bisa cepat dipanen, teknologi budidayanya mudah diadopsi oleh masyarakat, dan input produksi yang relatif kecil. Target produksi tersebut dapat dicapai melalui program ekstensifikasi pemanfaatan lahan potensial sekitar 4,5 juta ha, perbaikan teknologi budidaya sesuai pola musim dan karakteristik lahan masing-masing kawasan budidaya.

Upaya peningkatan produksi rumput laut juga tidak terlepas dari permasalahan, seperti ketersediaan bibit unggul dalam jumlah yang memadai pada waktu tertentu, adanya serangan penyakit, hama dan predator, serta adanya faktor pembatas musim tanam. Bibit rumput laut unggul dapat diperoleh dengan menggunakan metode seleksi massa dan bioteknologi seperti teknologi kultur jaringan dan rekayasa gen (Parenrengi et al., 2007a; 2007b; Parenrengi et al., 1994). Program seleksi massa dapat menghasilkan varietas bibit unggul dalam pertumbuhan relatif cepat, daya tahan terhadap penyakit dan lingkungan, serta keunggulan spesifik lokasi/kawasan. Protokol dalam buku ini dibatasi pada seleksi massa untuk menghasilkan bibit unggul rumput laut tumbuh cepat, dengan spesies target adalah cotoni (Kappaphycus alvarezii) dan Gracilaria (Gracilaria verrucosa). Daya tahan antar varietas rumput laut terhadap penyakit dan stres lingkungan adalah bervariasi. Oleh karena itu, beberapa varietas dan sumber bibit awal bisa digunakan dalam program seleksi dengan penekanan pada varietas lokal yang telah teradaptasi lama di suatu kawasan (Pong-Masak et al., 2011; Amini \& Parenrengi, 1994).

Keberhasilan budidaya rumput laut sangat dipengaruhi oleh kondisi lingkungan. Karena itu, kegiatan pemilihan bibit, seleksi harus memperhatikan faktor lingkungan perairan. Selanjutnya, variasi kondisi lingkungan perairan Indonesia relatif besar, sehingga program seleksi sangat dianjurkan untuk dilakukan di setiap sentra produksi rumput laut. Tujuan metode seleksi ini adalah untuk mendapatkan bibit unggul varietas rumput laut cottoni dan gracilaria yang cepat dalam pertumbuhan. Sasaran penerapan metode seleksi adalah penyediaan bibit unggul untuk mendukung target peningkatan produksi. Selain itu, sasaran dari program seleksi massa adalah penyediaan bibit untuk mendukung pengembangan kebun bibit di setiap sentra produksi.

\section{PEMILIHAN BIBIT}

Bibit rumput laut diperoleh dari hasil pengembangan budidaya atau dari kebun bibit adalah bibit yang diketahui memiliki keunggulan dibanding dengan sumber bibit lainnya (Rusman, 2010; Atmadja, 2010). Bibit yang akan digunakan harus bibit pilihan yang berkualitas dan dapat memenuhi kriteria benih rumput laut seperti pada Tabel 1.

Pemilihan bibit stok awal untuk dikembangkan pada kebun bibit atau yang akan diintroduksi untuk budidaya (Gambar 1) harus memiliki keunggulan dengan kriteria, sebagai berikut:

- Bibit yang memiliki adaptasi yang tinggi; LPH yang tinggi

- Bibit berumur 20-30 hari

- Penampilan batang/talus yang silindris, bersih, segar, keras, tidak berlendir, tidak berbau amis, dan tidak pucat

- Bibit dengan percabangan banyak dan tumbuh memusat dari satu bagian pangkal dan menyebar

- Bibit harus homogeni tidak tercampur dengan jenis yang lain

- Memilih bibit dengan talus memanjang berkisar $15-30 \mathrm{~cm}$ 
Tabel 1. Kriteria bibit rumput laut Gracilaria sp.

\begin{tabular}{ll}
\hline \multicolumn{1}{c}{ Kriteria } & \multicolumn{1}{c}{ Uraian } \\
\hline Spesifikasi & $\begin{array}{l}\text { Thallus silindris, licin, berwarna merah-coklat atau kuning hijau. Percabangan tidak beraturan, memusat di bagian } \\
\text { pangkal. Cabang-cabang lateral memanjang menyerupai rambut dengan ukuran panjang berkisar } 15-30 \mathrm{~cm}\end{array}$ \\
\hline Komposisi & Air 11,6\%; protein kasar 25,35\%, lemak 1,05\%, karbohidrat 43,10\%; serat 7,50\%; dan abu 11,40\% \\
\hline Gel strength & $220 \mathrm{~g} / \mathrm{cm}$ \\
\hline
\end{tabular}

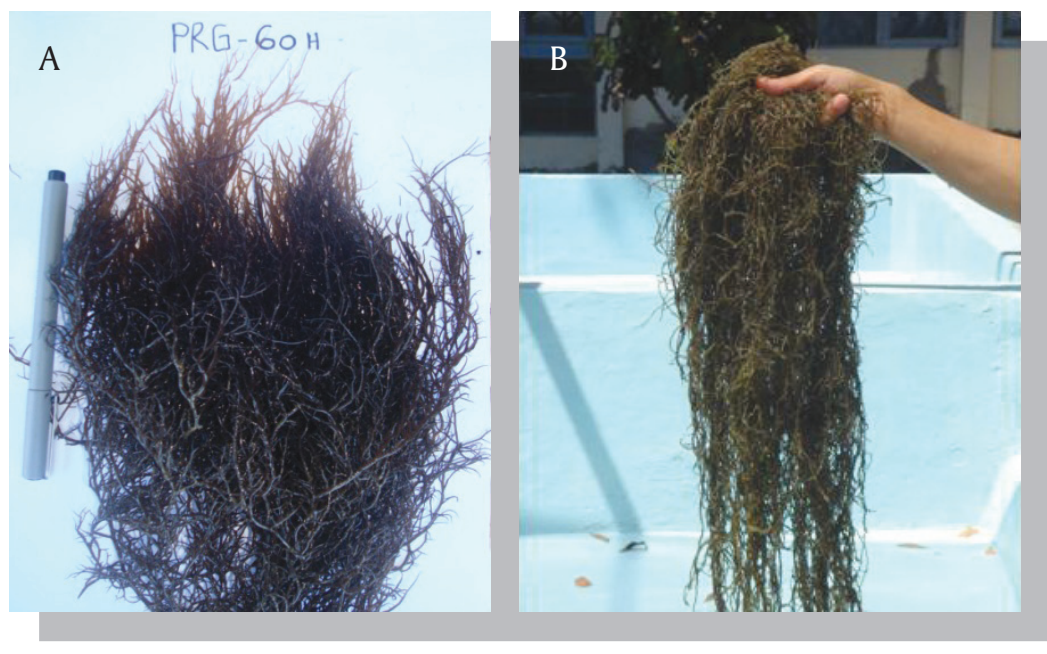

Gambar 1. Performansi bibit rumput laut Gracilaria verrucosa (A) dan Gracilaria gigas (B) untuk pengembangan budidaya

\section{PENYIAPAN KEBUN BIBIT RUMPUT LAUT Gracilaria}

Metode budidaya yang digunakan dalam kebun bibit dengan penerapan seleksi varietas adalah metode long line di tambak (Rusman, 2010).

\section{Protokol Seleksi}

Protokol ini masih bersifat general dan masih membutuhkan penyesuaian di lapangan tergantung pada kondisi lokal masing-masing kawasan budidaya. Metode budidaya yang diterapkan dalam program seleksi ini adalah metode long line. Protokol seleksi menitikberatkan pada hasil seleksi pertumbuhan thallus yang cepat.

Prosedur seleksi tahapan pada Gambar 2 merupakan tahapan pertama yang harus dilakukan dalam mempersiapkan bibit sebagai suatu proses produksi bibit unggul cepat tumbuh bagi pengembangan budidaya rumput laut, Gracilaria sp. Penjelasan mekanisme kerja dalam proses seleksi bibit dalam suatu area tambak sebagai kebun bibit, diuraikan pada skema Gambar 3.

\section{Persiapan Sarana Kebun Bibit}

Setelah pemilihan lokasi tambak, maka dilakukan persiapan dan konstruksi lokasi/tempat akan dilakukan seleksi bibit rumput laut (lihat materi "penyiapan lahan untuk teknis polikultur (Amini \& Parenrengi, 1994).

Konstruksi menggunakan balok kayu ukuran 4/6 sepanjang $2 \mathrm{~m}$ sebagai patok yang ditanam pada setiap sudut sehingga dapat digunakan untuk membentangkan tali bentangan bibit. Ukuran luasan sangat bergantung kepada kemampuan penanganan dan ketersediaan luasan tambak, misalnya berukuran luas $50 \mathrm{~m}$ x $30 \mathrm{~m}$ yang dapat memuat 50 tali bentangan. Panjang tali bentangan antara $30 \mathrm{~m}-50 \mathrm{~m}$. Setiap tali bentangan dibuat dengan $15 \mathrm{~cm}$ $25 \mathrm{~cm}$ jarak antar tali rumpun, sehingga setiap tali bentangan memuat 200-330 titik rumpun bibit untuk diseleksi. Jarak antar tali rumpun harus sama sehingga ruang untuk pertumbuhan bibit memiliki kesempatan yang sama, termasuk dalam memperoleh suplai nutrien dalam perairan. Demikian juga pada saat akan ditanam/ dibentangkan di laut pada tali induk, barisan tali bentangan harus diatur dengan jarak $1 \mathrm{~m}$ antar bentangan (Gambar $4)$.

\section{Penyediaan dan Penebaran Benih Ikan Bandeng}

Ke dalam petak tambak yang digunakan sebagai kebun bibit untuk produksi bibit unggul rumput laut, tetap dapat 


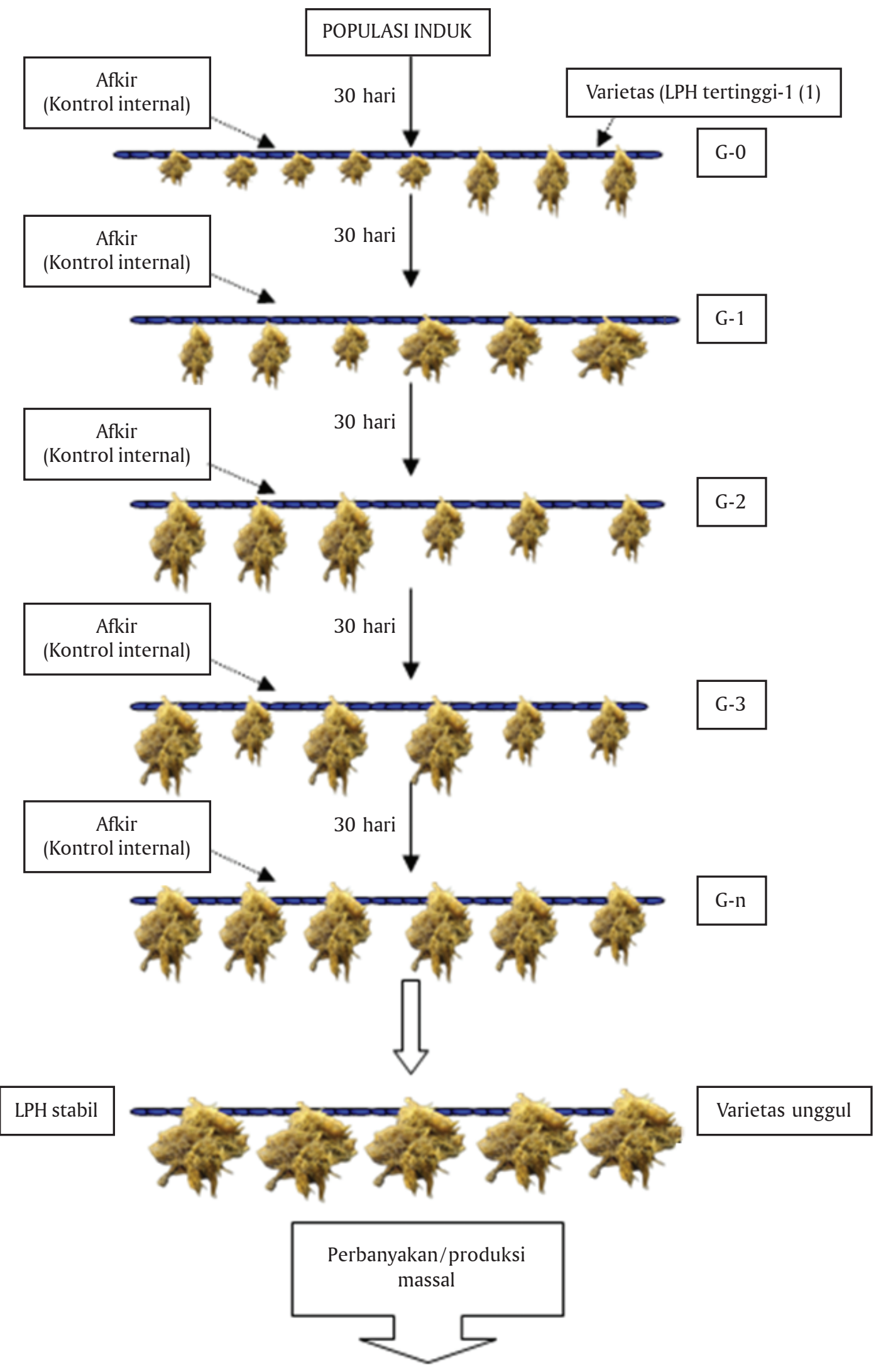

Gambar 2. Protokol seleksi bibit pada kebun bibit rumput laut untuk mendapat varietas bibit unggul yang cepat tumbuh 


\section{Populasi bibit awal (G-0)}

(40 $\mathrm{m}$ tali bentangan; 200 titik rumpun; $50 \mathrm{gr} /$ rumpun bobot awal bibit; $20 \mathrm{~cm}$ jarak antar rumpun; $1 \mathrm{~m}$ jarak antar bentangan; $30 \mathrm{~cm}$ dari permukaan perairan; jarak pelampung 2-3 $\mathrm{m}$ )

\section{0 hari pemeliharaan $(\mathrm{G}-1)$}

Ambil rumpun LPH tertinggi - 1 sebagai 1 varietas atau "n" varietas (per bentangan). Potong setiap varietas @ $50 \mathrm{~g}$ menjadi "n" rumpun (beri kode) + kontrol (internal dan eksternal)

\section{0 hari pemeliharaan $(\mathrm{G}-2)$}

Ambil rumpun LPH tertinggi - 1 sebagai 1 varietas atau "n" varietas (per varietas). Potong setiap varietas @ $50 \mathrm{~g}$ menjadi "n" rumpun dan beri kode (G2 varietas $1 \ldots$ n, bentangan ke 1...n) + kontrol (internal dan eksternal)

Catatan:

1. Setiap siklus pemeliharaan harus ada kontrol internal (Ki) (sumber bibit dari rataan bobot rumpun yang diseleksi) dan kontrol eksternal (Ke) (sumber bibit dari masyarakat pembudidaya lokal

2. Pemilihan lokasi kegiatan seleksi harus selektif, yakni lokasi yang memungkinkan pemeliharaan bibit sepanjang tahun, baik dengan menetap pada satu site atau dengan melakukan rotasi bentangan.

\section{0 hari pemeliharaan $(\mathrm{G}-3)$}

Ambil rumpun LPH tertinggi - 1 sebagai 1 varietas dari F1 varietas 1...n, Populasi B, bentangan ke 1...n. Potong @ $50 \mathrm{~g}$ menjadi "n" rumpun dan beri kode (F2 varietas $1 . . . n$, Populasi B, dari bentangan ke-n)

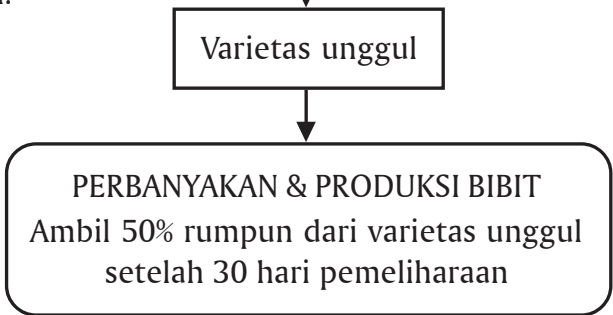

Gambar 3. Skema uraian tahapan seleksi varietas bibit Gracilaria untuk produksi bibit unggul cepat tumbuh 


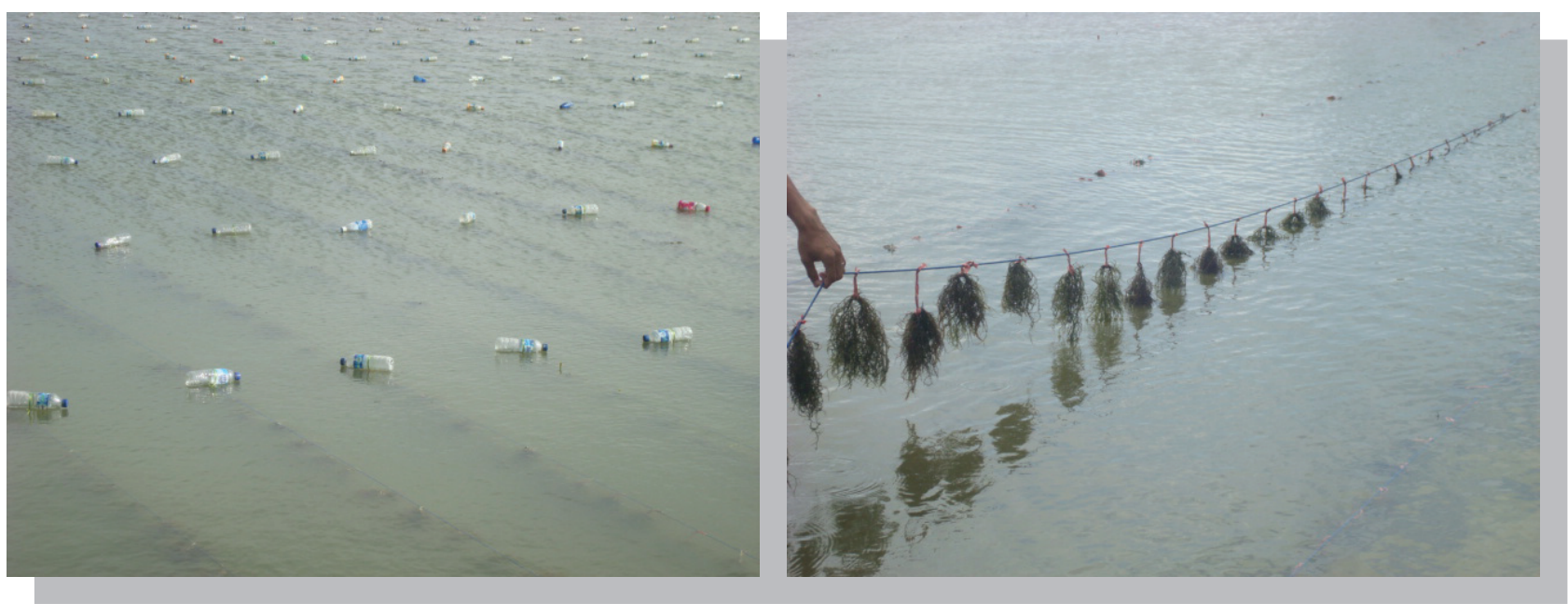

Gambar 4. Tali bentangan bibit dalam petak tambak sebagai media penempatan dan pemeliharaan varietas bibit yang akan diseleksi

dilakukan dengan sistem polikultur. Walaupun demikian harus diperhatikan bahwa pada kebun bibit yang utama adalah proses produksi bibit berkualitas. Penebaran gelondongan bandeng yang paling diutamakan karena perannya sebagai pengendali pertumbuhan gulma yang dapat menghambat pertumbuhan bibit (Gambar 5).

- Polikultur rumput laut dengan bandeng pada lahan 1 ha tambak idealnya digunakan rasio sebagai berikut: 2-2,2 ton bibit rumput laut: 2.000-2.500 ekor gelondongan ikan bandeng (Hasil Riset BRPBAP, lokasi di Marana Kabupaten Maros)

- Polikultur rumput laut, bandeng, dan udang pada lahan 1 ha tambak idealnya digunakan rasio sebagai berikut: 1,5 ton:1.000 ekor:5.000 ekor (Hasil Riset BRPBAP, Maros)

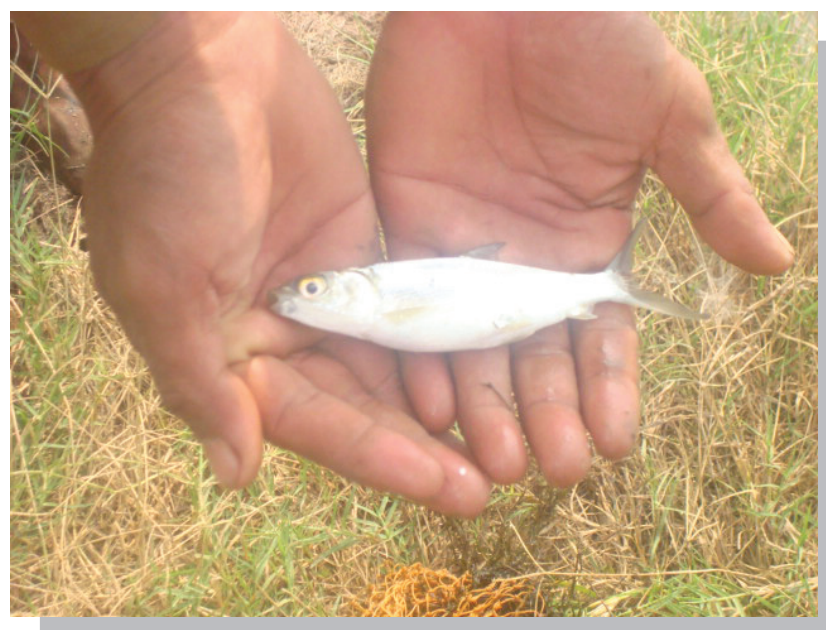

- Selain polikultur dengan bandeng dan udang, rumput laut juga dapat dipolikultur dengan komoditas lainnya, seperti rajungan, beronang, nila, maupun kepiting sebagai shelter

\section{Pengikatan dan Penanaman Bibit Gracilaria}

Penebaran bibit rumput laut, Gracilaria sp., umumnya menggunakan metode tebar dasar, namun untuk produksi bibit dengan metode seleksi varietas digunakan metode tali panjang. Hal ini dilakukan untuk mempermudah seleksi bibit terhadap varietas yang dipelihara (Gambar 6). Metode tali panjang adalah sebagai berikut:

- Mengikat bibit rumput laut pada simpul-simpul tali kemudian dibentangkan di bawah permukaan air dalam tambak pada kedalaman $10-20 \mathrm{~cm}$

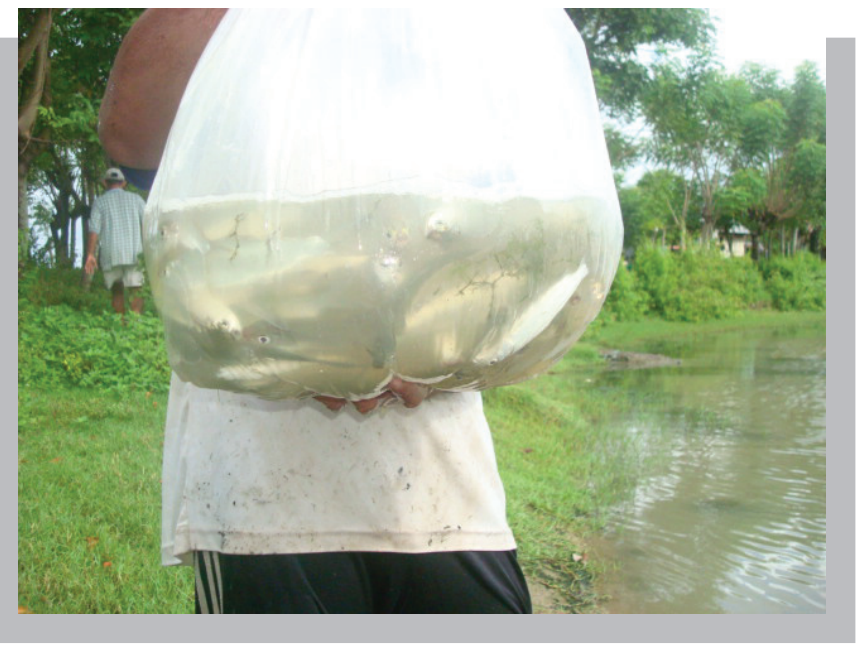

Gambar 5. Gelondongan bandeng ukuran 20-50 g untuk penebaran pada lahan budidaya rumput laut, Gracilaria sp. 


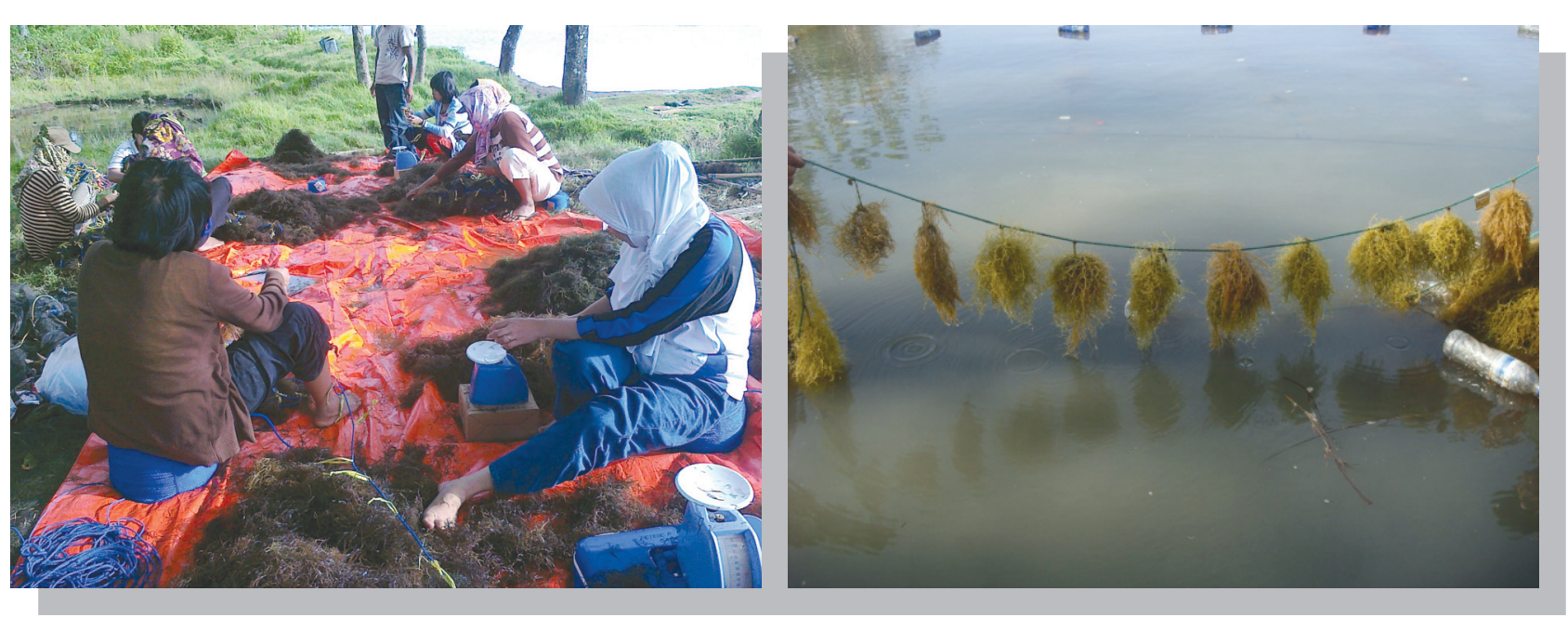

Gambar 6. Pengikatan bibit Gracilaria pada tali panjang untuk dibentangkan ke dalam petak tambak pemeliharaan bibit

- Jarak antar rumpun bibit 10-20 cm dengan bobot awal 10-25 g per rumpun

- Bibit yang sudah terikat pada tali dibentangkan memanjang dari satu sisi tambak dengan mengikatkan pada patok-patok kayu/bambu

- Metode budidaya tali panjang dapat dilakukan dengan polikultur udang dan/atau bandeng

- Metode ini juga masih terbatas dilakukan oleh pembudidaya

\section{Perawatan Bibit}

- Pada metode tebar dasar $\rightarrow 4$ minggu pertama ketinggian air dipertahankan $30 \mathrm{~cm}$; dan $50 \mathrm{~cm}$ pada minggu ke-5 sampai panen

- Melakukan pembersihan kotoran, dan membalik rumput laut

- Mengganti air 75\% (sekali dalam 1 minggu) $\rightarrow$ lebih sering pada musim kemarau

- Mengontrol dan membersihkan tanaman pengganggu (lumut dan kotoran lain yang menempel pada rumput laut),

- Menjaga kedalaman air minimal $60 \mathrm{~cm}$ untuk metode tebar lepas dasar dan minimal $80 \mathrm{~cm}$ untuk metode tali panjang

- Jika pertumbuhan rumput laut lambat/kerdil karena tambak kurang subur, pemupukan susulan $(20 \%$ dari dosis pupuk awal)

- Setelah umur penanaman 2-5 minggu $\rightarrow$ lakukan pengamatan dan penyebaran bibit yang bergerombol ke tempat yang kosong

- Pertumbuhan dipantau secara periodik $\rightarrow>3 \% /$ hari
- Ledakan populasi lumut terjadi pada tambak budidaya rumput laut merupakan masalah yang paling dominan, seperti jenis lumut: Enteromorpha sp., Chaetomorpha sp., dan Ectocarpus. Penanggulangan dapat dilakukan secara fisik dan biologi:

- Mengangkat lumut secara manual

- Meningkatkan ketinggian air tambak

- Resirkulasi air harian ditingkatkan

- Polikultur ikan bandeng, budidaya dampingan

- Kerang/teritip sering menempel pada talus rumput laut di tambak (Limnea glabra sp.)

\section{Teknis Seleksi Bibit Unggul per Generasi}

Teknis seleksi bibit Gracilaria sp. di tambak pada prinsipnya sama dengan teknis yang dilakukan pada jenis K. alvarezii (Ask \& Azanza, 2002) (Gambar 7). Populasi stok induk rumput laut yang telah dipisah menjadi rumpun dan telah dipelihara selama 30 hari setelah penanaman awal, maka dilakukan seleksi varietas dengan langkahlangkah kerja, sebagai berikut:

- Siapkan timbangan, wadah, dan tali baru/bersih untuk penimbangan bobot bibit, serta pemisahan dan pengikatan rumpun bibit dari varietas-varietas terbaik (DGR tertinggi -1) dan atau 10\%-20\% dari total yang terbaik

- Setiap bentangan bibit dilepas dari tali induk kemudian dibawa ke pematang tambak atau tempat yang teduh

- Bentangan diletakkan di atas terpal sebagai pengalas sehingga terhindar dari pasir, kotoran, dan kerusakan talus 


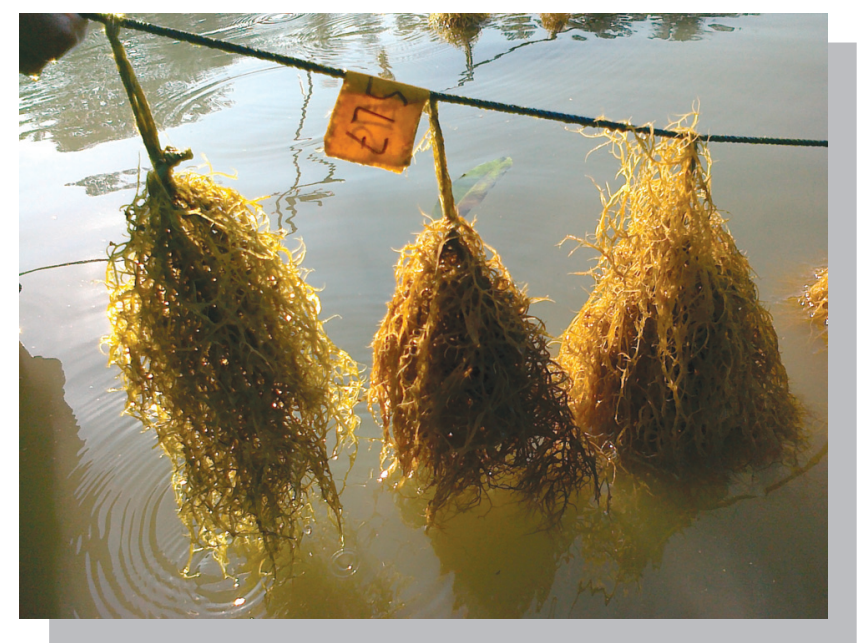

Gambar 7. Varietas bibit unggul rumput laut cepat tumbuh hasil seleksi varietas (Foto: Pong-Masak, 2011)

- Setiap rumpun bibit dilepas dari ikatannya, kemudian dilakukan penimbangan setiap rumpun bibit secara berurutan dalam setiap bentangan

- Setelah semua rumpun bibit dalam satu bentangan ditimbang, maka segera ambil bibit yang memiliki Laju Pertumbuhan Harian (LPH) sampai dengan nilai "LPH tertinggi -1”, kemudian dipisahkan dari populasi bentangan

- Setiap rumpun bibit yang terpilih masing-masing menjadi varietas yang akan dipisahkan/dipotong menjadi rumpun baru yang diikat dan dipelihara selanjutnya selama 30 hari
- Setiap siklus pemeliharaan harus ada kontrol internal dan kontrol eksternal

- Seleksi ke-2 dan seterusnya untuk mendapat varietas F-1...Fn dilakukan dengan proses yang sama dengan siklus sebelumnya sampai nilai memperlihatkan angka stabil

- Varietas-varietas rumpun bibit dengan LPH yang stabil, selanjutnya dilakukan uji performasi dan multilokasi.

- Apabila hasil pengujian performasi menunjukkan bahwa pertumbuhan varietas hasil seleksi lebih baik, maka varietas tersebut diklaim sebagai "Varietas Unggul" sebagai kandidat bibit yang akan dikembangkan

\section{Perbanyakan Bibit Unggul}

Bibit yang telah diklaim sebagai bibit unggul cepat tumbuh melalui protokol seleksi varietas, selanjutnya dilakukan perbanyakan dan setelah mencukupi sesuai kebutuhan maka dapat ditebar ke dalam petak budidaya pembesaran.

Proses perbanyakan dan pemeliharaan terhadap bibit hasil seleksi Galur-3 dengan melakukan perbanyak rumpun sesuai SOP perbanyakan bibit unggul (Gambar 8).

Melalui teknik produksi bibit unggul rumput laut tersebut di atas, maka konsep pengembangan kebun bibit yang selama ini dianut oleh instansi terkait yang hanya merupakan proses introduksi dan distribusi, seharusnya diubah dengan pola pengembangan kebun bibit dengan penerapan metode seleksi varietas. Adapun konsep pengembangan kebun bibit terdapat pada Gambar 9.

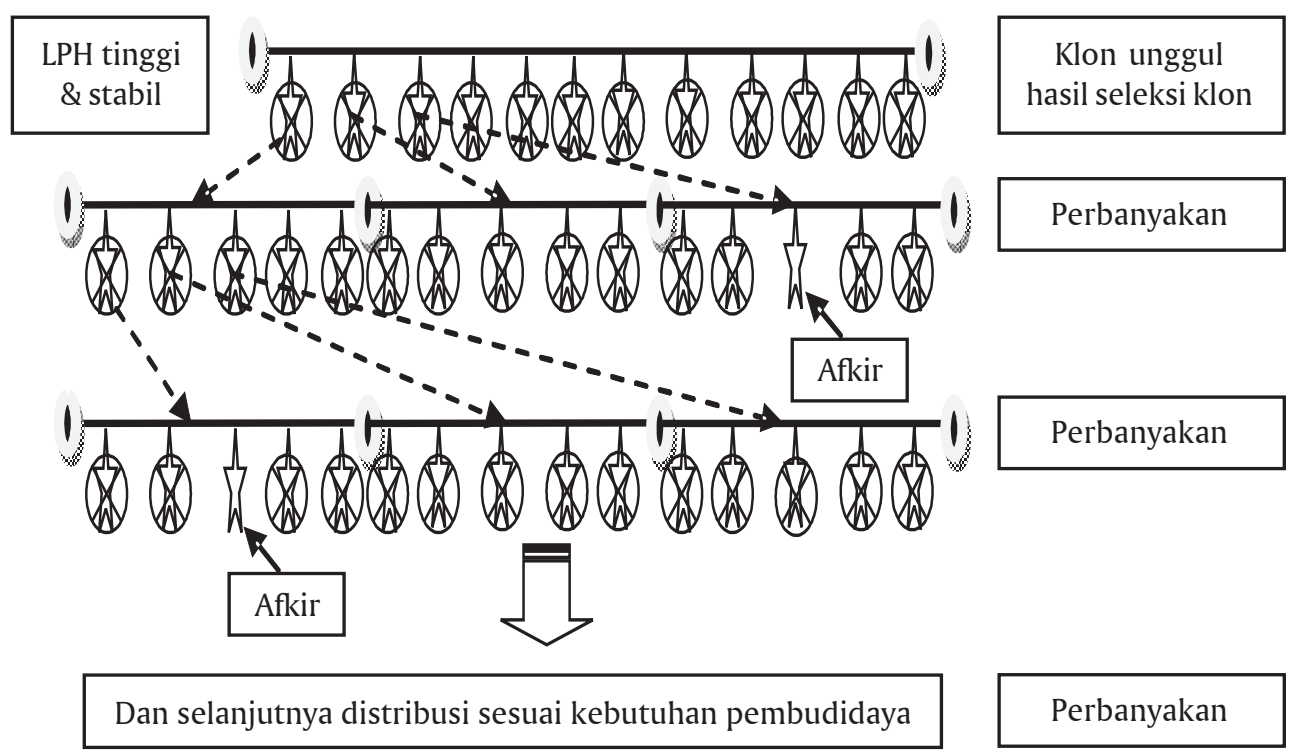

Gambar 8. Skema perbanyakan bibit unggul rumput laut cepat tumbuh hasil seleksi varietas 


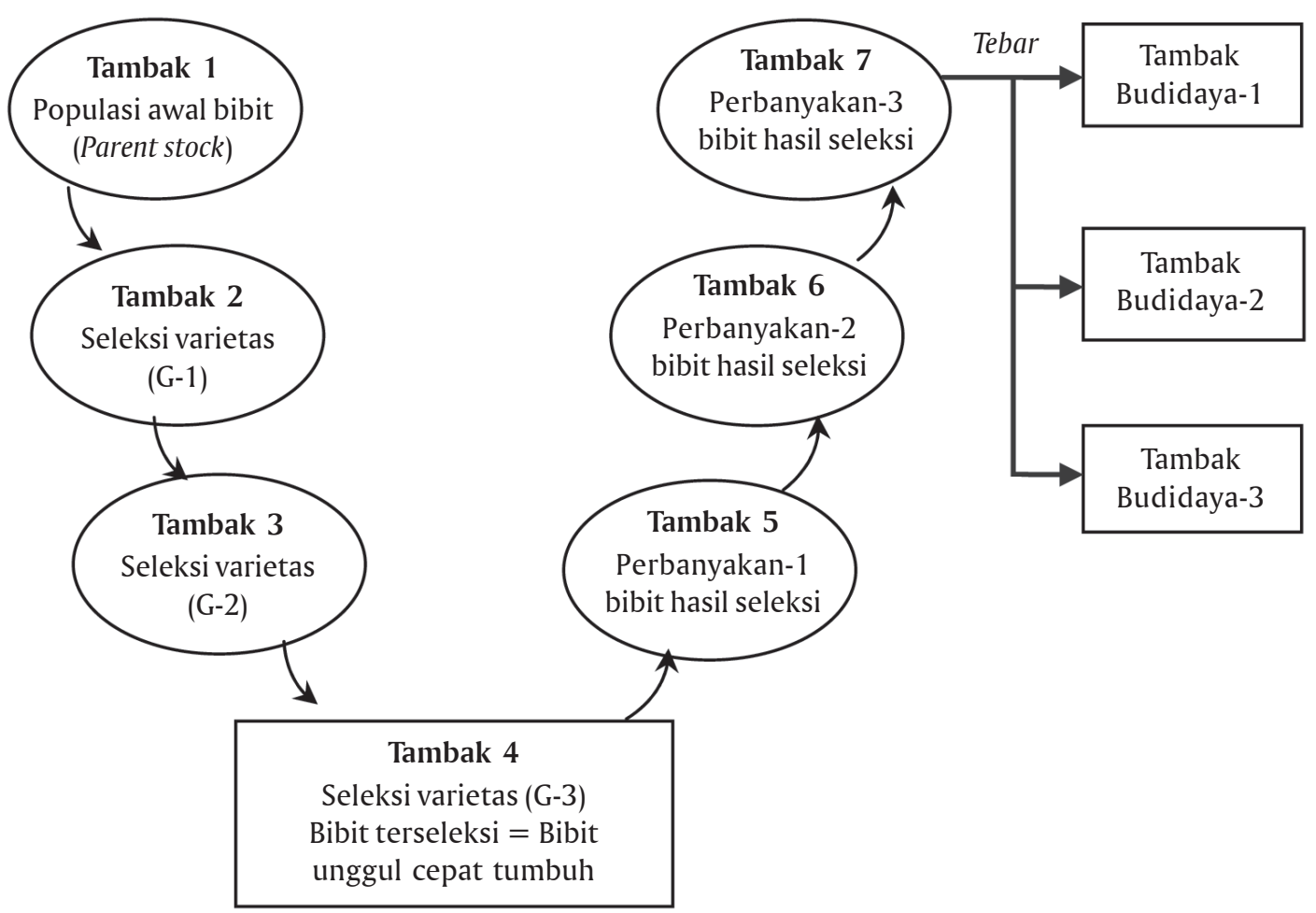

Gambar 9. Konsep pengembangan kebun bibit rumput laut, Gracilaria sp. di tambak

\section{PENEBARAN BIBIT}

Panen bibit dari kebun bibit harus secepatnya ditebar agar tidak mengalami stres sebelum ditebar. Demikian juga apabila bibit rumput laut Gracilaria sp. yang baru datang harus segera mungkin untuk ditanam. Tambak sebagai lokasi penanaman harus sudah disiapkan terlebih dahulu, agar bisa dilakukan penebaran bibit setelah tiba di lokasi.

Metode budidaya rumput laut Gracilaria sp. adalah metode tebar di tambak (Gambar 10). Metode budidaya yang lebih fleksibel dengan teknologi yang sederhana adalah metode tebar langsung di tambak baik secara monokultur maupun secara polikultur dengan bandeng. Metode tebar dasar dapat dimaksimalkan dengan menanam bibit secara long line di permukaan perairan sehingga dapat memaksimalkan kolom air (Gambar 11).

Metode budidaya rumput laut ini dikenal dengan istilah metode broadcast, di mana bibit ditebar langsung di dasar tambak dengan merata. Keuntungan metode ini adalah biaya lebih murah, penanaman, dan pengelolaannya lebih sederhana. Waktu penebaran sebaiknya pada pagi atau sore hari, untuk menghindari rumput laut dari teriknya sinar matahari.

Pada penanaman pertama, bibit rumput laut harus dipastikan satu spesies dan memiliki kualitas yang sangat baik dari bagian thallus yang lebih muda. Untuk penanaman selanjutnya dapat dilakukan dengan dari hasil budidaya.

\section{Perawatan}

Beberapa aspek yang harus diperhatikan selama pemeliharaan rumput laut Gracilaria adalah sebagai berikut:

a. Pergantian air sebaiknya dilakukan minimal sekali dalam seminggu dengan memanfaatkan kondisi pasang surut air laut agar unsur hara yang diperlukan rumput laut dapat tercukupi melalui aliran ganti air. Pergantian air akan lebih sering dilakukan pada musim kemarau untuk menghindari tingginya kadar garam akibat penguapan yang sering terjadi

b. Pengawasan terhadap kualitas air dilakukan minimal 1 kali seminggu khususnya kandungan kadar garam, suhu, dan kedalaman air

c. Sampai dengan minggu kedua pemeliharaan, kedalaman air dipertahankan sampai dengan kedalaman $40 \mathrm{~cm}$, sementara pada minggu selanjutnya ke dalam air diatur sekitar $60-70 \mathrm{~cm}$

d. Tambak yang kurang subur, pemupukan dilakukan dengan urea dan TSP masing-masing dengan dosis 50$75 \mathrm{~kg} / \mathrm{ha}$ pada pengolahan lahan dan pupuk susulan $20 \%$ dari pupuk awal pada saat tanaman berusia satu 


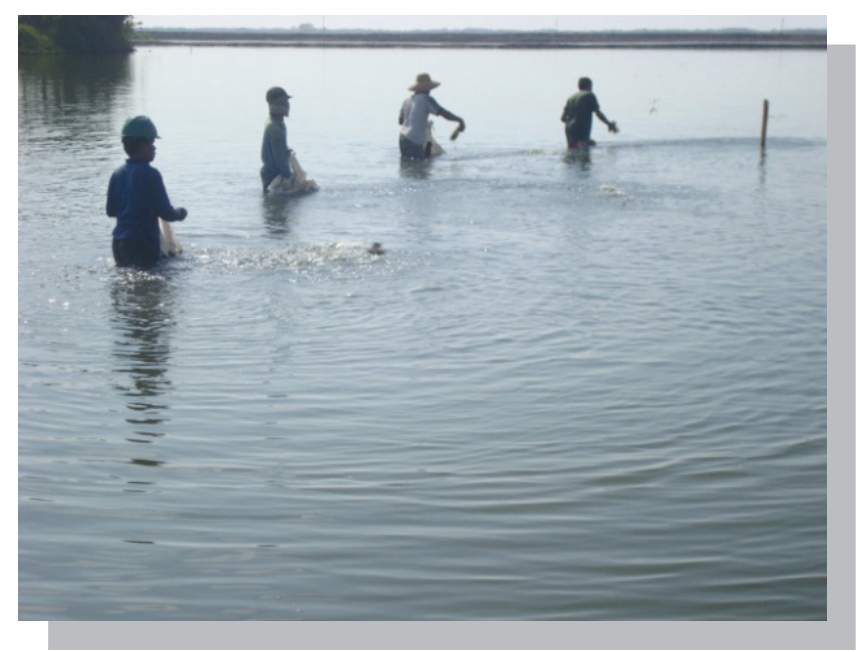

Gambar 10. Metode tebar dasar bibit rumput laut Gracilaria verrucosa

bulan. Pemupukan cukup dilakukan sekali dalam satu musim tanam

e. Apabila rumput laut mulai tumbuh subur sampai dengan umur dua minggu pertama, pemecahan bibit sudah besar menjadi 3-4 bagian, kemudian tebar kembali dengan merata pada semua permukaan dasar tambak. Apabila masih diperlukan, maka pada minggu keempat dilakukan lagi pemecahan bibit seperti minggu kedua sebelumnya. Selanjutnya rumput laut dipelihara sampai mencapai ukuran pada umur 2 bulan

f. Selama berlangsungnya pemeliharaan, perawatan rumput laut tetap harus dilakukan dengan cara membersihkan thallus dari tanaman pengganggu misalnya lumut, dan ganggang lainnya atau membuang kotoran lain yang menempel pada thallus rumput laut, seperti klekap yang berlebihan

g. Pertumbuhan tanaman harus dipantau secara berkala untuk mengetahui laju pertumbuhan hariannya. Laju pertumbuhan rumput laut diketahui dengan cara membuat petak kontrol yang ditimbang setiap minggu selama pemeliharaan berlangsung. Pertumbuhan rumput laut sebaiknya dipertahankan pada laju pertumbuhan tidak kurang dari 3\%/hari

\section{Pencegahan Hama dan Penyakit}

Hama umumnya terjadi pada saat musim kemarau yang ditandai dengan melimpahnya lumut sehingga memberikan persaingan dalam pemanfaatan unsur hara. Ledakan populasi lumut terjadi pada tambak-tambak dengan kedalaman air yang rendah serta kadar garam relatif tinggi pada musim kemarau (Largo et al., 1995). Cara mengatasinya adalah selain mengangkat lumut secara

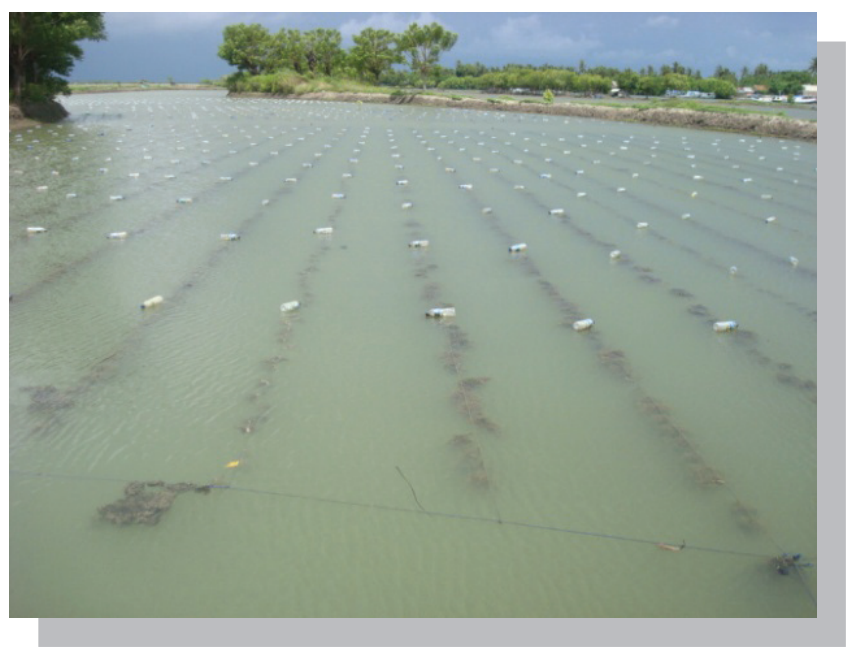

Gambar 11. Kombinasi metode tebar dasar dan long line bibit rumput laut Gracilaria verrucosa

manual juga dapat dikurangi dengan peningkatan ketinggian air budidaya. Selain itu, pada musim kemarau juga memungkinkan tumbuhnya teritip dan cacing pada thallus sehingga mengganggu proses fotosintesis rumput laut itu sendiri. Tetapi teritip tersebut akan lepas dengan sendirinya apabila telah memasuki musim hujan.

Gulma yang berupa lumut yang sering menyerang di tambak adalah terdiri atas jenis Enteromorpha sp., Chaetomorpha sp., dan Ectocarpus. Sedangkan jenis kerang sering menempel pada thallus rumput laut di tambak adalah jenis Limnea glabra sp. Gulma menyerang tanaman dengan cara melekat dan membelit rumput laut sehingga selain penyaing unsur hara juga dapat mengganggu pertumbuhan rumput laut. Pemberantasan hama tersebut selain dapat dilakukan dengan cara langsung membuang lumut dari tambak, juga dapat dilakukan dengan cara biologis dengan memasukkan ikan bandeng sebanyak 2.500 ekor/ha dengat bobot sekitar 15-20 g (Gambar 12). Ikan tersebut memakan lumut yang mengganggu tanaman tersebut. Apabila gulma yang menyerang rumput laut sudah berkurang atau habis dimakan ikan sementara ikan bandeng sudah mulai bertumbuh maka dengan segera ikan tersebut dipanen. Sedangkan hama kerang yang selain menempel juga memakan rumput laut dapat diatasi melalui penanganan secara manual dengan cara mengambil langsung kerang tersebut pada tanaman rumput laut.

\section{PENUTUP}

Dengan Program seleksi varietas diharapkan produksi rumput laut dapat mencapai 10 juta ton pada tahun 2014. Selain itu, protokol ini diharapkan dapat diterapkan di setiap kawasan kebun bibit untuk dapat memperoleh bibit 


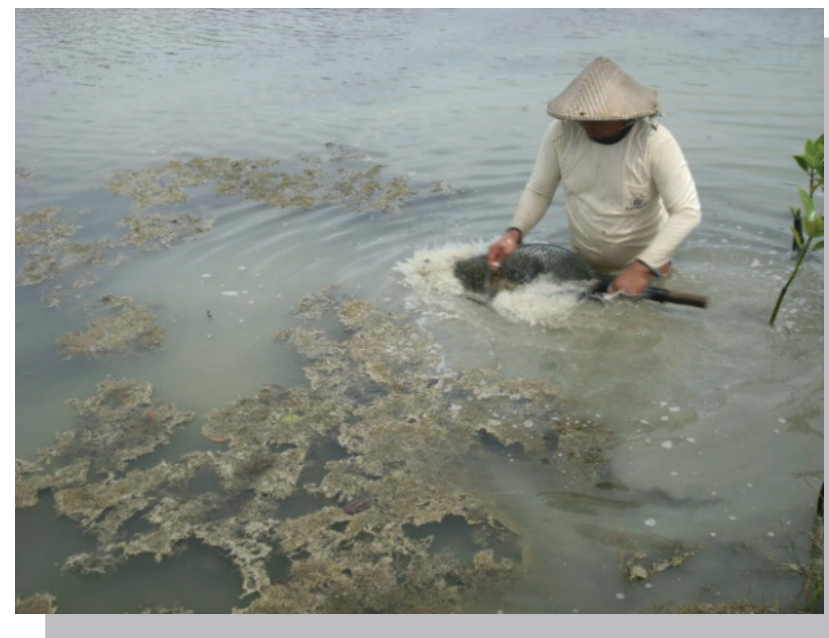

Klekap dalam petakan budidaya Gracilaria

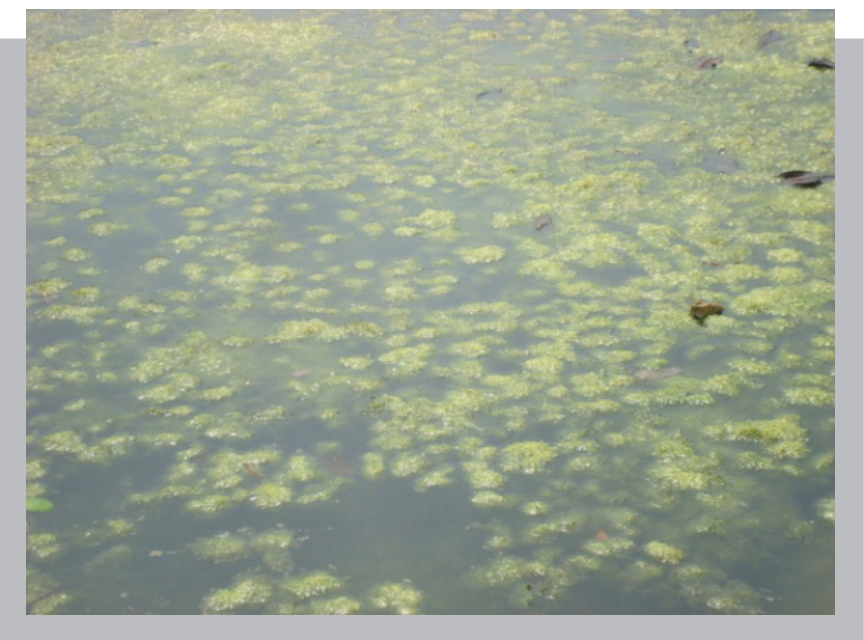

Blooming pertumbuhan lumut sutra dalam petakan budidaya Gracilaria

Gambar 12. Selain cara fisik, cara pencegahan secara biologi terhadap klekap dan lumut adalah melalui penebaran bandeng secara polikultur dengan rumput laut

unggul yang spesifik kawasan, sehingga dapat mempercepat tersedianya bibit unggul di setiap sentra pengembangan budidaya rumput laut. Metode seleksi varietas ini masih bersifat general sehingga perlu penyempurnaan agar lebih mempermudah aplikasinya ditingkat pembudidaya (Atmadja, 2010). Dengan demikian dapat memberikan hasil yang maksimal bagi peningkatan produksi serta perbaikan pendapatan pembudidaya rumput laut di Indonesia.

Pelaksanaan program seleksi harus didukung oleh sumberdaya manusia yang memiliki pengetahuan dan keterampilan yang memadai serta dukungan dana yang cukup. Selanjutnya distribusi dan teknik transportasi bibit unggul harus mendapat perhatian yang baik. Pemanfaatan rumput laut secara luas oleh masyarakat pembudidaya akan diperlukan upaya-upaya percontohan atau penyuluhan. Di masa datang, operasionalisasi kebun bibit untuk menghasilkan bibit unggul rumput laut dan pemasaran hasil dapat dikelola oleh kelompok pembudidaya.

\section{DAFTAR ACUAN}

Anonim. 2005. Profil rumput laut Indonesia. Direktorat Jenderal Perikanan Budidaya, Departemen Kelautan dan Perikanan, $152 \mathrm{hlm}$.

Anonim. 2010. Produksi rumput laut di Indonesia. Direktorat Jenderal Perikanan Budidaya, Kementerian Kelautan dan Perikanan.

Anggadiredja, J.T. 2007. Prospek Pasar Rumput Laut Indonesia di Pasar Global. Makalah disampaikan pada Lokakarya Implementasi Program Berkelanjutan Sulawesi
Selatan Menuju Sentra Rumput Laut Dunia, Makasar, 7 Mei 2007, $24 \mathrm{hlm}$.

Amini, S. \& Parenrengi, A. 1994. Perbanyakan benih rumput laut Gracilaria verrucosa secara in vitro pada berbagai perlakuan pupuk berbeda.J. Pen. Budidaya Pantai, 10(2): 29-34.

Amini, S. \& Parenrengi, A. 1995. Pengaruh Variasi Komposisi Pupuk Terhadap Pertumbuhan Rumput Laut, Eucheuma cottonii Pada Kultur In Vitro. J. Pen. Perik. Indonesia, I(3): 47-53.

Atmadja, W.S. 2010. Keunikan Reproduksi Rumput Laut. Prosiding Seminar Nasional Rumput Laut dan Minisimposium Mikroalga II di Widya Graha LIPI, Jakarta Tanggal 22-23 Juni 2010, hlm. 78-92.

Ask, E.I. \& Azanza, R.V. 2002. Advances in cultivation technology of commercial eucheumatoid species: a review with suggestions for future research. Aquaculture, 206: 257277.

Largo, D.B., Fukami, F., Nishijima, T., \& Ohno, M. 1995. Laboratory-induced development pf the ice-ice disease of the farmed red algae Kappaphycus alvarezii dan Eucheuma denticulatum (Solieriaceae, Gigartinales, Rhodophyta).J. Appl. Phycol., (7): 539-543.

Parenrengi, A., Amini, S., \& Amin, M. 1994. Pertumbuhan benih Gracilaria verrucosa hasil kultur jaringan pada berbagai berat awal yang berbeda di Panati Barru, Risalah Seminar, Balai Riset Perikanan Budidaya Pantai, hlm. 77-84.

Parenrengi, A., Madeali, M.I., \& Rangka, N.A. 2007a. Penyediaan benih dalam menunjang pengembangan 
budidaya rumput laut. Makalah disampaikan pada Workshop Rumput Laut, Sangiaseri Pemerintah Provinsi Sulawesi Selatan, Makassar, hlm. 23-59.

Parenrengi, A., Sulaeman, Suryati, E., \& Tenriulo, A. 2007b. Karakteristik Genetik Rumput Laut Gracilaria verrucosa dari Beberapa Sumber. J. Aquacultura Indonesiana, 8 (3): 177-182.

Pong-Masak, P.R., Tjaronge, M., Parenrengi, A., \& Rachmansyah. 2011. Produksi Bibit Unggul Rumput Laut, Kappaphycus alvarezii Cepat Tumbuh dengan Metode Seleksi Varietas. Makalah dipresentasikan pada acara Seminar Forum Inovasi Teknologi Akuakultur (FITA) Tanggal 22-23 Juli 2011 di Denpasar, Bali. In process, 12 hlm.

Rusman. 2010. Petunjuk Teknis Budidaya Rumput Laut. Balai Budidaya Laut Lombok. NTB.

Sulaeman, Parenrengi, A., Suryati, E., \& Tenriulo, A. 2005. Genetical and morphological differences of two different variety of seaweed Kappaphycus alvarezii. Paper presented at World Aquaculture Society, Denpasar 9 13 May 2005, 5 pp. 